\title{
Synthesis and Characterization of Novel Red-Light-Emitting Materials with Push-Pull Structure Based on Benzo[1,2,5]thiadiazole Containing Arylamine as an Electron Donor and Cyanide as an Electron Acceptor
}

\author{
Jin Uk Ju, Sung Ouk Jung, Qing Hua Zhao, Yun Hi Kim, ${ }^{\dagger,+}$ Jong Tae Je,,+ and Soon Ki Kwon ${ }^{\star}$ \\ School of Nano \& Atwanced Materials Science and Engineering and ERI. Gveongsang National Chiversin, \\ Jin Ju 660-701, Korea. E-mail: shiwoniàgsnu.ach hr \\ ${ }^{\dagger}$ Department of Chemistry and RINS, Gleongsang National Universitv, Jin Ju 660-701. Korea. "E-mail: whimägnuack \\ -SFC CO., LTD Ochang Techno Iillage 641-5, Cheongwon 363-883. Korea \\ Received October 12,2007
}

\begin{abstract}
New efficient red emitter haxing short $\pi$-conjugation length and asymmetric bulky structure, 2-(7diphenylamino-benzo[ $[1,2,5]$ thiadiazole-t-ylmethylene)-malononitrile. was synthesized and characterized. Using this material as a dopant. we fabricated electroluninescence device with a structure of ITO/DNTPD/ $\mathrm{NPD} / \mathrm{BTZA}$ ( $5 \mathrm{wt} \%$ in $\mathrm{Alq})_{3} / \mathrm{Alq}_{3} / \mathrm{LiF} / \mathrm{Al}$. The device exhibited a high brightness of $761 \mathrm{~cd} / \mathrm{m}^{2}$ at a driving voltage of $4.8 \mathrm{~V}$, and current efficiency is $0.75 \mathrm{~cd} / \mathrm{A}$. The Commission Intentational de I'Eclairage (CIE) coordinates of the EL device were found to be $(0.62,0.37)$ at $10 \mathrm{~mA} / \mathrm{cm}^{2}$
\end{abstract}

Key Words : Benzo[1.2.5]thiadiazole. Push-pull. Inhibited intermolecular interaction. Amorphous

\section{Introduction}

Organic light-emitting diodes (OLEDs) have attracted a great deal of attention and numerous approaches to their fabrication have been proposed. OLEDs offer a number of advantages over conventional displays. such as faster response time, high efficiency, high color purity, low-roltage driving requirements. and simplicity. ${ }^{1-5}$ Despite considerable progress that has been made over recent decades in this area. full-color OLEDs still require inprovement in terms of efficiency. purity, durability, manufacturing process. and cost. These factors in turn depend on the evolution of high efficiency OLEDs materials, including RGB enitters. ${ }^{6-\delta}$ For realization of full-color. efficient emitting materials of all three prinary colors (red, green. blue) are required. ${ }^{9.10} \mathrm{~A}$ number of green and blue emitting materials with reasonable color purity have been reported. ${ }^{11}$ However in comparison with green and blue emitting materials. red emitting materials remain deficient. owing to the following problents. ${ }^{12.13}$ First. the small energy gap between the highest occupied molecular orbital (HOMO) and the lowest unoccupied molecular orbital (LUMO) of the red-light emitters. results in non-radiative relaxation of the excited states. ${ }^{14.15}$ Second the materials have several problems such as color-purity, stability and efficiency, owing to the strong intermolecular dipole-dipole interactions or intermolecular $\pi$-stacking. as a result of their polar or extensive $\pi$-conjugated structures. This leads to a high tendency of aggregation and so-called concentration quenching. ${ }^{16.17}$ Consequently. most red OLEDs always use a dopant sy'stem. Third, most of the red light enitting materials are complicated and give the funal product in low yield. ${ }^{18}$

In this paper. we report efficient red emitter having short $\pi$-conjugation length and așymmetric bulky structure. 2-(7- diphenylamino-benzo[1.2.5] thiadiazole-4-y methylene)malononitrile. The introduced triphenylamine is electron donating group to benzothiadiazole as well as hole transporting group, and the introduced malonitrile is electron withdrawing group as well as electron transporting group Thus. the new red emitting material with push-pull structure is expected to have high efficiency by restraining intermolecular dipole-dipole interaction due to its bulky and asymmetric structure. Furthermore, it is also expected to have high efficiency due to a charge balance of the triphenylamine group. which serves as a hole transporting moiety, and the cyanide group. which functions as an electron transporting moiety.

\section{Experimental Section}

\section{Synthesis}

+-Bromo-benzo[1,2,5]thiadiazole (1) (BBTD). A mixture of benzo[1.2.5]thiadiazole $(5.0 \mathrm{~g} .36 .8 \mathrm{mmol})$ in aq $\mathrm{HBr}(48 \%, 15 \mathrm{~mL})$ was heated to reflux with stirring. while $\mathrm{Br}_{2}(2.8 \mathrm{~mL}, 110$ mmol) was added slowly within $1 \mathrm{~h}$. Towards the end of the addition. the mixture became a suspension. To facilitate stirring aq. $\mathrm{HBr}(48 \% .10 \mathrm{~mL})$ was added. and the mixture was heated to reflux for $2 \mathrm{~h}$ after completion of the $\mathrm{Br}_{2}$ addition. The mixture was filtered while hot. cooled. filtered again. and washed well with $\mathrm{H}_{2} \mathrm{O}$. The compound was dried $\left(\mathrm{Na}_{2} \mathrm{SO}_{4}\right)$ and recrystallized $(\mathrm{MeOH})$ to afford $1(6.3 \mathrm{~g} .81 \%)$ : ${ }^{1} \mathrm{H}$ NMR $(300 \mathrm{MHz}$. $\left.\mathrm{CDCl}_{3}\right) \delta 8.00-8.03(\mathrm{~m} .1 \mathrm{H}) .7 .81-7.84(\mathrm{~m} . \mathrm{lH}) .7 .43-7.50$ (m. lH).

t-Bromo-7-bromomethyl-benzo $[1,2,5]$ thiadiazole (2) (BMTD). Compound 1 (5 g. $23.2 \mathrm{mmol}$ ) was dissolved in a mixture of $48 \%$ aqueous hydrobromic acid $(100 \mathrm{~mL})$ and glacial acetic acid $(25 \mathrm{~mL})$ and then trioxane $(5 \mathrm{~g} .56 \mathrm{mmol})$ 
and trimetlyl(tetradecyl)ammonium bromide $(0.2 \mathrm{~g})$ were added. The mixture was stirred and refluxed for $24 \mathrm{~h}$. After cooling, the green solid was filtered and washed with water and ethanol. The compound was recrystallized (toluene) to afford $2\left(5.4 \mathrm{~g} .75 \%\right.$ ). ${ }^{\mathrm{l}} \mathrm{H} \mathrm{NMR}\left(300 \mathrm{MHz} . \mathrm{CDCl}_{3}\right) \delta 7.82$ (d. lH), 7.72 (s. IH), 7.55 (d, lH). $4.94(\mathrm{~s}, 2 \mathrm{H})$.

7-Bromo-benzo $[1,2,5]$ thiadiazole-t-carbaldehyde (3) (BBTC). Compound $2(2.5 \mathrm{~g} .10 .3 \mathrm{mmol})$ was taken in a round botton flask along with sodium periodate $\left(\mathrm{NaIO}_{4}\right)$ $(0.42 \mathrm{~g} .2 \mathrm{mmol})$. The above mixture was dissolved in 30 $\mathrm{mL}$ of $N, N$-dimethylformamide (DMF). The reaction mixture was heated at $150^{\circ} \mathrm{C}$. The progress of the reaction was monitored by thin layer chromatography by comparison with the starting material ( $10 \%$ ethyl acetate in hexane). The reaction was completed in $40 \mathrm{~min}$. The reaction mixture was cooled and treated with $20 \mathrm{~mL}$ of water and then extracted with diethyl ether. The combined ether layers were dried over anhydrous magnesium sulfate $\left(\mathrm{MgSO}_{4}\right)$, then filtered off and concentrated. Evaporation of the solvent and purification by chromatography on silica gel (ethyl acetate/ hexanes: 1:2). The compound was obtained $3(2.2 \mathrm{~g} .73 .6 \%)$. ${ }^{1} \mathrm{H}$ NMR (300 MHz. $\left.\mathrm{CDCl}_{3}\right) \delta 10.76$ (s. $\left.1 \mathrm{H}\right) .7 .88$ (d. $\mathrm{lH}$ ). 7.54 (d. $1 \mathrm{H}$ ).

7-Diphenylamino-benzo[1,2,5]thiadiazole-t-carbaldehyde (4) (DBTC). Under nitrogen atmosophere of Compound 3 $(2.0$ g. $8.22 \mathrm{mmol})$. dipheny lamine $(1.99 \mathrm{gg} .11 .78 \mathrm{~mm}$ ol). dppf (6.3 g. $12.33 \mathrm{mmol}) . \mathrm{NaOtBu}(0.04 \mathrm{~g} .0 .41 \mathrm{mmol})$, and $\mathrm{Pd}_{2}(\mathrm{dba})_{3}(0.5 \mathrm{~mol} \%)$ in toluene $(30 \mathrm{~mL})$ was stirred and heated at 120 for $8 \mathrm{~h}$. After cooling to room temperature. saturated ammonium chloride solution was added to the reaction. The solution was extracted with ethyl acetate and dried over anhydrous magnesium sulfate $\left(\mathrm{MgSO}_{4}\right)$. then filtered off and concentrated. Evaporation of the solvent and purification by chromatography on silica gel (ethyl acetate/ hexanes: 1:2). A greenish yellow solid was obtained 4 (2.1 $\mathrm{g}$. $77.1 \%$ ). ${ }^{\text {l}} \mathrm{H}$ NMR $\left(300 \mathrm{MHz}, \mathrm{CDCl}_{3}\right) \delta 10.55$ (s. IH). 8.08 (d, $1 \mathrm{H}) .7 .33-7.39(\mathrm{~m} .4 \mathrm{H}), 7.27(\mathrm{t}, 2 \mathrm{H}), 7.13-7.17(\mathrm{~m}, 4 \mathrm{H})$. $7.08(\mathrm{~d} . \mathrm{lH})$.

2-(7-Diphenylamino-benzo $[1,2,5]$ thiadiazole-4-ylmethylene)-malononitrile (5) (BTZA). Compound 4 (2 g. 4.23 mmol). malononitrile (0.81 g. $8.45 \mathrm{mmol})$, and basic aluminium oxide $(2 \mathrm{~g})$ are stirred in toluene $(20 \mathrm{~mL})$ for $8 \mathrm{~h}$ at $70{ }^{\circ} \mathrm{C}$. After cooling to room temperature, the reaction solution was filtered. The filterate was subjected to flash column chromatography' (silica gel. dichloromethane/hexanes: 1:2). A red solid was obtained $5(1.62 \mathrm{~g} .70 .7 \%){ }^{1} \mathrm{H}$ NMR ( $\left.300 \mathrm{MHz}_{2} \mathrm{CDCl}_{3}\right) \delta 8.64-8.71(\mathrm{~m}, 3 \mathrm{H}) .7 .96-8.02(\mathrm{~m}$. $2 \mathrm{H}) .7 .82$ (t. lH). 7.63-7.68 (m. 2H). 7.44-7.52 (m. 3H). 7.15 (d. $1 \mathrm{H}$ ): EI-MS $m z$ (relative intensity) $379\left(\mathrm{M}^{+} .100 .0\right), 380$ (27.97), 381 (7.8). 382 (1.47). Analalysis Calcd for $\mathrm{C}_{22} \mathrm{H}_{13} \mathrm{~N}_{5} \mathrm{~S}$ : C. $69.64 ; \mathrm{H}, 3.45 ; \mathrm{N}, 18.46 ; \mathrm{S}, 8.45$. Found: C, $69.72 ; \mathrm{H}$. 3.62: S. 8.87. FT-IR $\left(\mathrm{KBr} . \mathrm{cm}^{-1}\right.$ ): 3010 (aromatic $\mathrm{C}-\mathrm{H}$ ), 2253 $(\mathrm{C} \equiv \mathrm{N}), 1587(\mathrm{C}=\mathrm{N}) .1542,1495(\mathrm{C}=\mathrm{C}) .1235(\mathrm{C}-\mathrm{N})$.

Instruments for characterization. The ${ }^{1} \mathrm{H}$ NMR spectra were recorded with a Bruker AM-200 spectrometer. The FTIR spectra were measured on a Bomen Michelson series FTIR spectrometer. The mass spectrometry (MS) were mea- sured on a JMS-700. The melting points were deternined with an Electrothermal model 1307 digital analyzer. The thermal analysis were performed on a TA TGA 2100 thermogravimetric analyzer in a nitrogen atmosphere at a rate of $20^{\circ} \mathrm{C} / \mathrm{min}$. Differential scanning calorimetry (DSC) was conducted under nitrogen on a TA Instrument 2100 differential scanning calorimeter. The sample was heated at $20^{\circ} \mathrm{C} / \mathrm{min}$ from 30 to $220^{\circ} \mathrm{C}$. UV-vis absorption spectra and photoluminescense spectra were measured with a PerkinElmer Lambda-900 UV-vis/IR spectrophotometer and an LS-50B luminescence spectrophotometer. respectively. The photoluminescense spectra were reacted on a PerkinElmer LS-50 fluorometer with a lock-in amplifier system with a chopping frequency of $150 \mathrm{~Hz}$. Cyclic voltammetry was performed on an EG\&G Parc 273- $\AA$ potentiostat/galvanostat system with a three-electrode cell in a solution of $\mathrm{Bu}_{4} \mathrm{NClO}_{4}$ $(0.1 \mathrm{M})$ in acetonitrile at a scanning rate of $100 \mathrm{Mv} / \mathrm{S}$.

Organic light-emitting diode (OLED) fabrication. Prepatterned indium tin oxide (ITO) substrates were cleaned by sonication in a detergent solution for $2 \mathrm{~min}$ and then washed with a large amount of doubly distilled water. Further sonication in ethanol for $2 \mathrm{~min}$ was done before blowing dry with a stream of nitrogen. The ITO substrates were then treated with $\mathrm{O}_{2}$ plasma for one minute before being loaded into the vacuum chamber. The organic layers were deposited themally at a rate of $0.1-0.3 \mathrm{~mm} \mathrm{~s}^{-1}$ under a pressure of about $10^{-6}$ torr. OLEDs devices were constructed with $60 \mathrm{~nm}$ of DNTPD as the hole injection layer. $20 \mathrm{~nm}$ of NPD as the hole transporting layer. $20 \mathrm{~mm}$ of BTZA $(5 \mathrm{wt} \%$ in $\mathrm{Alq}_{3}$ ) as the emission layer. $40 \mathrm{~mm}$ of $\mathrm{Alq}_{3}$ as the electron transporting emission layer. $0.5 \mathrm{~nm}$ of $\mathrm{LiF}$ as the electron injection layer and $50 \mathrm{~nm}$ of $\mathrm{Al}$ as the cathode. The $\mathrm{EL}$ was measured under ambient conditions.

\section{Results and Discussion}

The overall synthetic routes are outlined in Scheme 1. As shown in Scheme 1. compounds 1-5 were prepared with highly overall yields. Bromination of 1 by bromine afforded 4-bromo-benzo[1.2.5] thiadiazole (1) (BBTD) with $81 \%$ yield. 4-Bromo-7-bromomethyl-benzo[1.2.5] thiadiazole (2) (BMTD) was obtained by allylic bromination. 7-Bromobenzo[1.2.5]thiadiazole-4-carbaldehyde (3) (BBTC) was obtained by a formylation reaction through allylic bromination. The following arylamination of the aldehydecarrying 7-diphenylamino-benzo[1.2.5] thiadiazole-4-carbaldehy'de (4) (DBTC) was readily performed in the presence of 1.1'-bis(diphenylphosphino)ferrocene. $\mathrm{NaOtBu} . \mathrm{Pd} z(\mathrm{dba})_{3}$, and diphenylamine. Toluene was found to be the most suitable as reaction solvent with $77.1 \%$ yield. Finally: malononitrile was condensed in Knoevenagel conditions (basic $\mathrm{Al}_{2} \mathrm{O}_{3}$ in dry toluene) with aldelyde with 4 to form the dicyanovinyl electron-withdrawing group of the red emitting 2-(7-diphenylamino-benzo[1.2.5]thiadiazole-4-ylmethylene)malononitrile (5) (BTZA) compound. Our strategy was successfully carried out with high yield.

The resulting compounds were examined by spectroscopy 

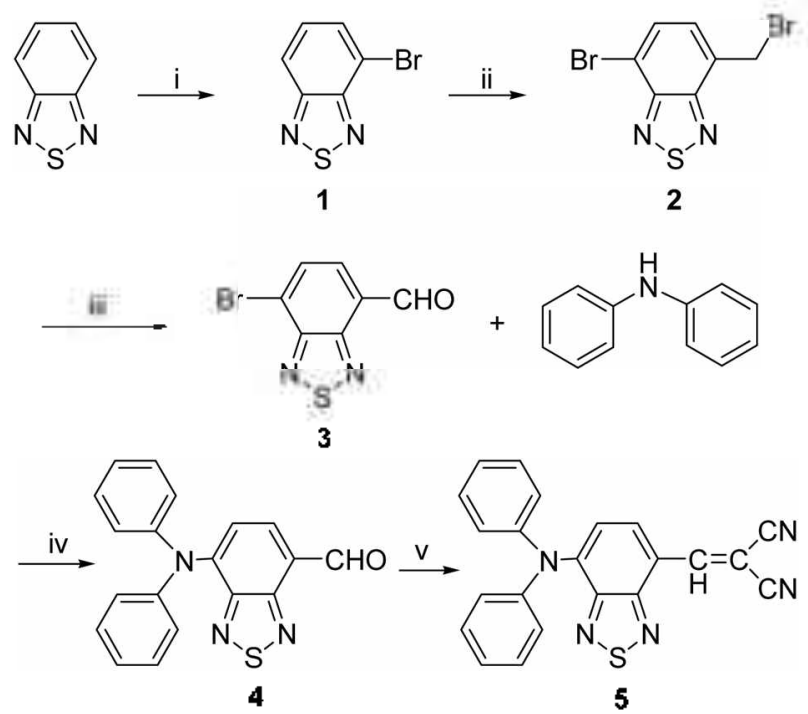

Scheme 1. Synthetic procedure for the emitter. Reagent i, $\mathrm{HBr}, \mathrm{Br}_{2}$ : ii, trioxane, trimethyl(tetradecyl lanmonium bromide, $\mathrm{HBr}, \mathrm{AcOH}$ : iii, $\mathrm{NaIO}_{4}, \mathrm{DMF} ; \mathrm{iv}$, dppf, $\mathrm{NaOtBu}, \mathrm{Pd}_{2}(\mathrm{dba})_{3}$, diphenylamine, toluene; $\mathrm{v}$, malononitrile, basic $\mathrm{Al}_{2} \mathrm{O}_{3}$, toluene.

analyses. The structure of BTZA was identified by ${ }^{\text {}} \mathrm{H}$ NMR. FT-IR. mass spectrometry (MS), and elemental analysis. The thernal properties of BTZA were exanined via a themogravinetric analy is (TGA) and differential scanning calorimetry (DSC). Despite being a small molecule, BTZA showed a glass transition temperature of $130^{\circ} \mathrm{C}$. suggesting that the material could form homogeneous and amorphous film through thennal evaporation. The $5 \%$ weight loss of BTZA was observed at $267^{\circ} \mathrm{C}$.

The optical properties of BTZA were examined using UVvis and photoluminescence (PL) spectra. Figure I shows the normalized UV-vis absorption and PL spectra of BTZA. The absorption maximum of BTZA was observed at $532 \mathrm{~lm}$ for solution and $561 \mathrm{~nm}$ for film, respectively. A red shift in the absorption maxima was observed from solution to film. which was similar with solvato chromic effect. indicating that this molecule exhibits intramolecular charge transfer character in the ground state. ${ }^{19}$ The optical band gap of

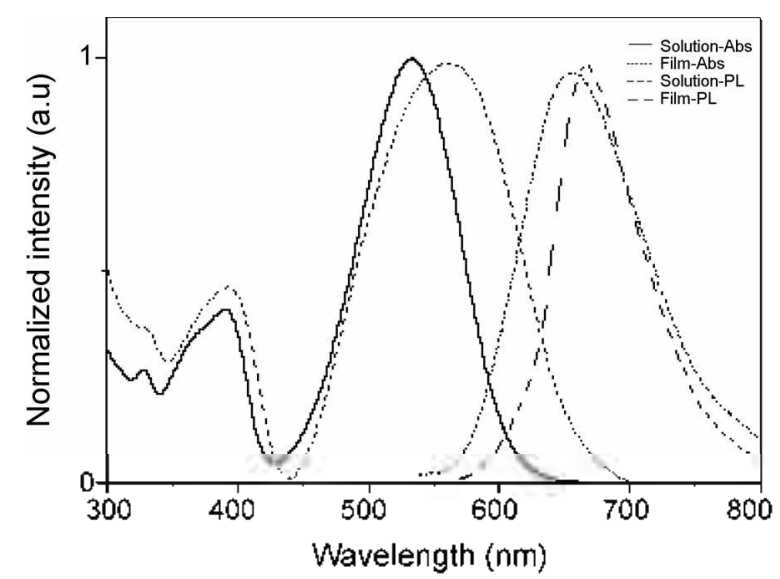

Figure 1. Nornalized UV-vis spectra absorption and photoluminescence spectra of BTZA.

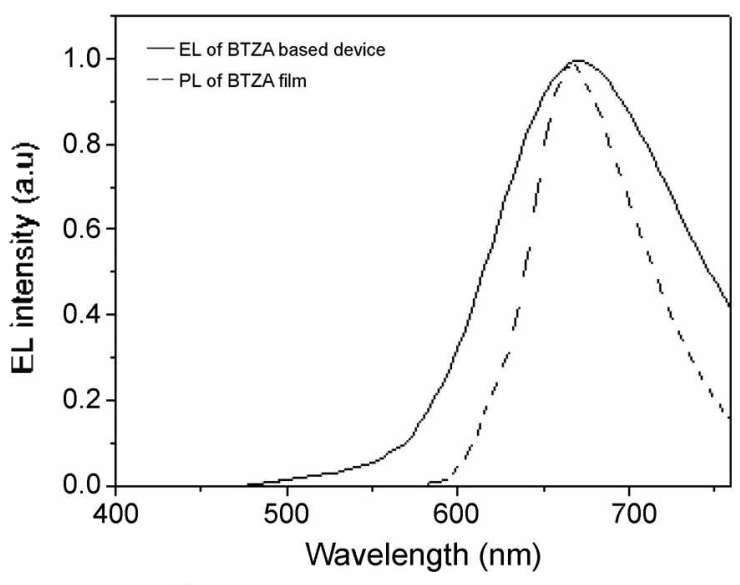

Figure 2. PL and $E L$ spectra of the BTZA.

BTZA was $2.07 \mathrm{eV}$. calculated from the threshold of the absorption edge at $599 \mathrm{~lm}$. The PL maximum of BTZA was found at $655 \mathrm{~nm}$ for solution and $665 \mathrm{~nm}$ for film, respectively. Therefore, the new material emitted red emission despite having short conjugation. Moreover. it did not show shoulder emission at long wavelength due to the charge transfer complex and excimer formation. Electrochemical properties of BTZA were examined using cyclic voltanmetry $(\mathrm{CV})$. CV measurement of BTZA in $0.1 \mathrm{M}$ solution of tetraanmonium perchlorate $\left(\mathrm{Bu}_{4} \mathrm{NClO}_{4}\right) /$ acetonitrile solution was carried out. A platinum plate was used as the working electrode, a platinum wire as the counter electrode, and $\mathrm{Ag} / \mathrm{Ag}^{-}$as the reference electrode. ${ }^{\text {?il }}$ The reduction onset of BTZA was $-0.7 \mathrm{eV}$. Using this value. the LUMO of BTZA was calculated as $-3.54 \mathrm{eV}$ by ferrocene correction. From the LUMO and optical band gap. the HOMO level of BTZA was determined to be $-5.61 \mathrm{eV}$. The EL properties of BTZA were investigated using a device fabricated with the following configuration: ITO/DNTPD/NPD/BTZA (5 wt $\%$ in $\left.\mathrm{Alq}_{3}\right) / \mathrm{Alq} / \mathrm{LiF} / \mathrm{Al}$. ITO was employed as the anode, DNTPD for hole injection. NPD for hole transporting. BTZA ( $5 \mathrm{wt} \%$ in $\mathrm{Alq}_{2}$ ) as the red emitting material, $\mathrm{Alq}_{3}$ for

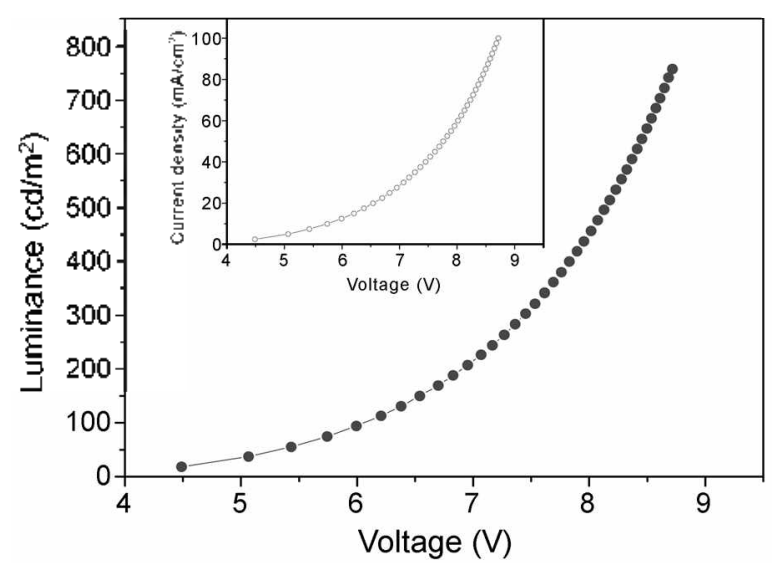

Figure 3. Luminance-voltage characteristics of ITO/DNTPD/NPD/ $\mathrm{BTZA}$ (5 $\mathrm{wt} \%$ in $\mathrm{Alq}$ ) $/ \mathrm{Alq} / \mathrm{LiF} / \mathrm{Al}$. (Inset: Current-density characteristics $]$. 


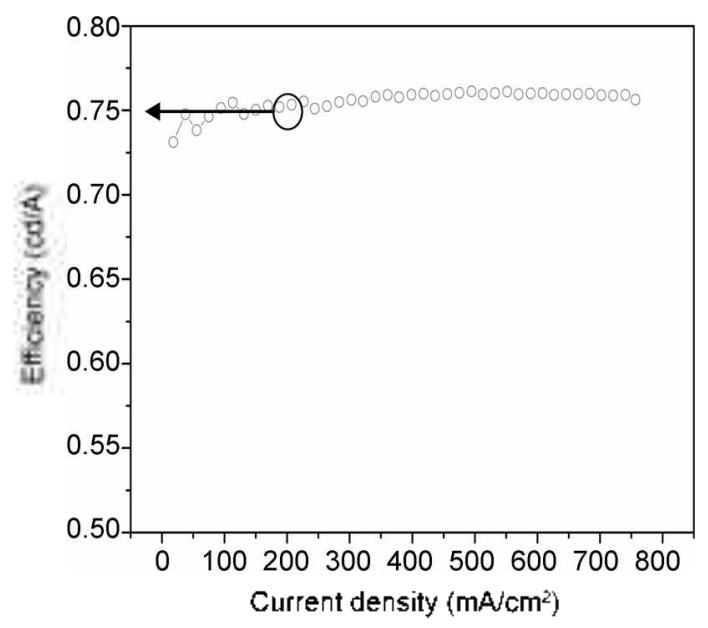

Figure 4. Efficiency versus current density of BTZA.

electron transporting. $\mathrm{LiF}$ for electron injection. and $\mathrm{Al}$ as the cathode. ${ }^{2]}$ The EL spectrum of the device is shown in Figure 2. The EL maximum was at $671 \mathrm{~mm}$. The Commission International de I'Eclairage (CIE) coordinates of the EL device were fould to be $(0.62,0.37)$ at $10 \mathrm{~mA} / \mathrm{cm}^{2}$. The luninescence-roltage and current-roltage characteristics of the BTZA device are shown in Figure 3. The maximum brightness of BTZA was $76 \mathrm{l} \mathrm{cd} / \mathrm{m}^{2}$ with a turn-on voltage of $4.8 \mathrm{~V}$. Figure 4 shows the efficiency versus current density characteristics of the BTZA device. Here. we can observe stable efficiency $(0.75 \mathrm{~cd} / \mathrm{A})$ even with increased current density. Device optimization is currently being carried out in order to increase the maxinum brightness and efficiency.

In summary. we designed and synthesized 2-(7-diphenylamino-benzo[ $[1,2.5]$ thiadiazole-4-ylmethylene)-malononitrile (5) (BTZA) as a red emitting material. where arylamine serves as an electron donor and cyanide plays the role of an electron acceptor (i.e., a push-pull system). The new red emitting material was simply and successfully sy'nthesized with high yield. BTZA emitted red light with a peak at 671 num and CIE coordinates of $(0.62 .0 .37)$ at $10 \mathrm{~mA} / \mathrm{cm}^{2}$. The maximum brightness of BTZA was $761 \mathrm{~cd} / \mathrm{m}^{2}$ with a stable efficiency of $0.75 \mathrm{~cd} / \mathrm{A}$

Acknowledgment. This study was financially supported by the Ministry of Conmerce, Industry and Energy (MOCIE) of Korea (10030834) and Research Foundation Grant (KRF-
2004-D0025 I). We are grateful to the second stage of BK 21 program for supporting a fellowship and Y. H. Kim thanks for the Gyeongsang National University.

\section{References}

1. Masayoshi. N.: Shibasaki. Y.: Mitsuru. U.: Tugita. K.: Ichikawa. M. Taniguchi. Y. Hacomolecules 2004, 37. 1204.

2. Kim. Y. H; Jeong. H. C ; Kim. S. H.: Yang. K. Y; Kwan, S. K. Adw Funct Mater $\mathbf{2 0 0 5}, 15.1799$.

3. Ikai. M.: Ishikawa. F.: Osuka. N. A. A.: Kawabata. S.: Kajioka. T.: Takeuchi. H.: Fujikawa. H.: Taga. Y. Adt: Fimct. Mater. 2006. 16. 515.

4. Kim. Y. H.: Lee, S. J.: Jung. S. Y.: Byeon, K. N.: Kım, J. S.: Shin. S. C. Kwon, S. K. Bull. Konean Chem. Soc, 2007, $28(3)$. 43 .

5. Kwon. S. K.: Kım, Y. H.: Shın, S. C. Bull. Korean Chem Soc. 2002. $23(1) .17$

6. Yao. Y. S.: Xiac. J.: Wang. X. S.: Deng. Z. B.: Zhang. B. W. Ad: Fimct. Hater 2006. 16. 709 .

7. Kim. Y. H.; Kwon. S. K. J. Appl. Polym. Sci. 2006. 100, 2151

8. Kim. Y. H.: Aln. J. H.; Shin, D. C.: Kim. J. H.: Park, Y. W. Choi. D. S.: Kim, Y. K. Kwon. S. K. Bull. Korean Chem. Soc. 2001. $22(11) .1181$.

9. Qiu. Y:: Wei. P.: Zhang. D.: Qiao. J: Duan. L.: Li. Y.: Gao. Y: Wang. L. Ad Hater 2006. 18. 1607.

10. Kim. Y. H; Jung, S. Y.: Jung, S. O.: Park. M. H.: Kwon. S. K. d. Polym Sci. Part A: Potm. Chem. 2006. H4. 4923.

11. Lim. S. T.: Chun, M. H; Lee. K. W.: Shın, D. M. Optical Iaterials 2002. 21, 217 .

12. Choi. K. S.: Lee. C. H.: Lee. K. H.: Park. S. J.: Son. S. U.: Chung. Y. K.: Hong. J. I. Bull. Korean Chem. Soc. 2006. 27(10). 1549.

13. Fantg. Q.: Jiang. B. X. B.: Chent. H. F.: Cao. A. Chent Conmum. 2005.1468 .

14. Hsieh, B. R. Macromol. Symp. 1997, 49, 125.

15. Zhao, Q. H.: Kim, Y. H.; Dang. T. T. M.; Shin. D. C.: You. H.: Kwon. S. K. J. Polvnt Sci. Part A: Polnm Chent 2007. 45. 341 .

16. (a) Picciolo. L. C.: Murata. H.: Kafafi. Z. H. Appl Phns. Lett. 2001. 78, 2378. (b) O'Brien. D. F.: Baldo. M. A.: Thompson, M. E.; Forrest, S. R. J. Appl. Phys. Lett. 1999. 74. 412.

17. (a) Suzuki. H: Hoshino, S. J. Appl. Phys 1996. 79. 8816. (b) Kido. T.: Hongawa. K.: Okuyama. K.: Nagai. K. J. Appl. Phos. Letf. 1994. 64.815.

18. Choi. K. S.: Lee. C. H.: Lee. K. H.: Park. S. J.: Son. S. U.: Chung. Y. K.: Hong. J. I. Bull. Kowan Chem. Soc, 2006, 27(10). 1549.

19. Wang, P. W: Xie, Z.: Tong. S.; Wong, O.: Lee, C.-S.: Wong. N.; Hung. L.: Lee. S. Chent Matert 2003. 15. 1913.

20. Kim. Y. H.: Shin. D. C.: Kim. S. H.: Ko. C. H.: Yu. H. S.: Chae. Y. S.: Kwon. S. K. Ad Hater: 2001. $13(22) .1690$.

21. Jung. S. O Kang. Y. J.: Kim. H. S.; Kim. Y. H. Lee. C. L. Kim. J. J.: Lee, S. K.: Kwon. S. K. Ew: J. horg Chem. 2004. 3415 . 